organization of the educational process. The effectiveness of the educational process is possible only if the correct combination of lecture material with independent work of students of higher education. After all, the development of skills of promising constructions requires systematic independent practical work on the material: solving problems, performing individual tasks, creative work. This is devoted to a third of the study time provided by the curriculum of the specialty for the course.

\title{
References:
}

1. Bovkun S. A. Linear perspective : textbook. Zaporozhye: ZNTU, 2017. 116 p. URL: http://eir.zntu.edu.ua/bitstream/123456789/2527/1/ Bovkun_Tutorial_on_discipline.pdf (date of access: 11.11.2021).

2. Zaika O. Development of graphic literacy in future teachers of mathematics. Collection of scientific works of uman state pedagogical university. Uman, 2018. No. 2. P. 89-98. URL: https://doi.org/10.31499/ 2307-4906.2.2018.149223 (date of access: 24.11.2021).

DOI https://doi.org/10.30525/978-9934-26-173-2-48

\section{ОСОБЛИВОСТІ РОЗВИТКУ ВОКАЛЬНОГО ДИХАННЯ У ПРОЦЕСІ ПІДГОТОВКИ МАЙБУТНЬОГО ВИКЛАДАЧА МИСТЕЦЬКОЇ ШКОЛИ}

\author{
Процишина О. Ю. \\ аспірантка кафедри музикознавства та музичної освіти \\ Київський університет імені Бориса Грінченка \\ м. Київ, Україна
}

Сучасний викладач мистецької школи для вирішення актуальних питань вокальної педагогіки повинен володіти глибокими знаннями 3 теорії та методики навчання співу, знати особливості будови та функціонування голосового апарату, у тому числі й органів дихання. Щоб досягнути педагогічної майстерності майбутньому викладачу мистецької школи у процесі фахової підготовки у ЗВО слід оволодіти традиційними методиками постановки голосу та сучасними методами розвитку творчих, вокальних навичок учнів. Серед таких методів важливе місце посідають методи розвитку та вдосконалення вокального (співацького) дихання. 
Вітчизняні та зарубіжні науковці (Л. Дмитрієв, Я. Кушка, А. Менабені, В. Микиша, В. Морозов, Л. Работнов, Ю. Юцевич та інші) досліджуючи теоретичні та практичні питання вокальної педагогіки велику увагу приділяють визначенню особливостей співацького дихання. Ми погоджуємось 3 твердженням Л. Дмитрієва, що досліджувати питання вокального дихання та практично розвивати його окремо від інших органів голосового апарату недоцільно, адже робота органів дихання тісно пов'язана із функціонуванням гортані та артикуляційного апарату. Від їхньої взаємодії залежить якість вокального звуку, його основні характеристики такі як: висота, сила та тембр [1, с. 347].

Робота над вдосконаленням вокального дихання повинна відбуватися у процесі фонації тобто співу. За Л. Дмитрієвим вокальне дихання - «це дихання, яке скоординоване з усіма іншими частинами голосового апарату в процесі співу. Хороше вокальне дихання у того співака, який правильно організовує співоче звучання голосу, а не в того який може повільно вдихати і видихати або довго затримувати дихання» $[1$, c. 382]. Ми погоджуємося з науковцем та стверджуємо, що робота над вдосконаленням вокального дихання повинна відбуватися у процесі роботи над вокальним звуком. Тонус дихальних м'язів напряму впливає на роботу голосових зв'язок, на положення гортані, на звучання нижніх та верхніх резонаторів. Проте існує багато дихальних вправ, які об'єднані у цілі системи, методики, які активно використовуються у вокальній педагогіці. Ми погоджуємося з думкою А. Менабені, що такі вправи на розвиток дихання не можна відносити до методів удосконалення вокального дихання, а лише як дихальну гімнастику, яка підвищить тонус м'язів дихальної системи, покращить відчуття дихальної мускулатури та посилить контроль співаком «вдиху та видиху». Науковець застерігає, що в деяких випадках окрема робота над диханням без вокалізації може не мати позитивного ефекту при співі [2].

Прийнято вважати найоптимальнішим типом дихання при співі саме нижньореберно-діафрагмальний. Проте так було не завжди. Навіть у наш час можна зустріти співаків, які користуються іншим типом дихання - грудним, при цьому досконало володіючи голосом. Як зазначає Л. Дмитрієв, перехід від грудного до грудодіафрагмального типу відбувся приблизно в середині XIX ст. На основі історичних розвідок науковець приходить висновку, що зміна типів дихання залежала від характеру звуку, виконавського стилю, який панував у той чи інший історичний період. Від співаків вимагалось володіння конкретною манерою голосоутворення, щоб виконувати певну арію [1, с. 354]. 3 розвитком естрадної музики популярності набули вокальні методики, в основу яких покладено «розмовну позицію». Зазначимо, що органи голосоутворення, у тому числі і органи дихання по-різному працюють у співацькій та розмовній фонації. 
Вокальне дихання має три фази: вдих, затримка, видих. Вдих повинен бути активним та достатньо глибоким з відчуттям напівзівка, швидкість набирання повітря відповідає темпу та характеру твору; затримка дихання триває до 1 секунди та необхідна для фіксації м'язового тонусу, створення правильного підзв'язкового тиску, необхідного для вокального звукоутворення, відчуття опори дихання; видих повинен бути економним, плавним, рівномірним та контрольованим, його тривалість та інтенсивність залежить від фразування та штрихів. Залишок повітря після видиху слід «скинути» перед новим вдихом.

Найпоширенішим $є$ твердження, що вдих повинен бути змішаним - через рот і ніс. При набиранні повітря через ніс краще відчувається повнота і глибина вдиху, проте не завжди у процесі виконання твору можливе вдихання носом. Повітря при співі набирається безшумно, щоб не пересушувати голосові складки. На початковому періоді навчання співу слід вокальний вдих поєднувати 3 правильною м'язовою установкою ротоглотки - одночасне підняття м'якого піднебіння.

Існує безліч різноманітних методів діагностики вокального дихання та його розвитку. Н. Фоломєєва наводить практичні рекомендації для перевірки ефективної роботи м'язів при грудо-діафрагмальному диханні: слід лягти на спину, руки покласти на зону діафрагми і зробити вдих-видих. Якщо органи дихання працюють вірно, то в процес будуть залучені діафрагма та м'язи живота, які будуть припіднімати долоні вверх при вдихові та опускати при видиху. За таким самим принципом потрібно проконтролювати дихання в положенні сидячи та стоячи [3].

Отже, у процесі вокальної підготовки майбутніх викладачів мистецької школи велика увага приділяється вивченню теорії та методики навчання співу. Студент повинен оволодіти теоретичними знаннями та практичними навичками співу та вокальної педагогіки. У роботі над розвитком співацького голосу спершу слід налаштувати на правильний режим співацьке дихання. Майбутньому викладачу слід знати будову та функції органів дихання, класифікацію типів дихання, особливості дихання під час співу, характеристику звуку на опорі, методи роботи над розвитком співацького дихання.

\section{Література:}

1. Дмитриев Л. Основы вокальной методики : учеб. пособие. Москва : Музыка, 1968. 677 с.

2. Менабени А. Методика обучения сольному пению: учеб. пособие. Москва : Просвещение, 1987.95 с.

3. Фоломєєва Н. Виконавська майстерність естрадного співака : навч.-метод. посіб. Суми, 2021. 169 с. 